\title{
Icteric Type of Infectious Mononucleosis in A 2-Month-old Infant
}

\author{
By \\ Tasuke Shibuya \\ From the Department of Pediatrics, Faculty of Medicine, Tohoku \\ University, Sendai; Director: Prof. Ts. A rakawa
}

(Received for publication, July 30, 1962)

The occurrence of infectious mononucleosis in infancy has been said to be rare in Japan ${ }^{1-4)}$ as well as abroad..$^{5-8)}$ Among the reported cases of infants with infectious mononucleosis, the youngest is 4-months in age. ${ }^{9)}$ Furthermore, there is no report, within our knowledge, dealing with infantile cases with jaundice due to infectious mononucleosis-hepatitis. In the present paper the author wishes to report a 2-month-old infant with jaundice due to infectious mononucleosis-hepatitis and discuss the liver biopsy findings from diagnostic point of view.

\section{CASE REPORT}

Y.Y., a 70-day-old boy: His parents and a brother are well and living. He was born with birth-weight of $3,150 \mathrm{~g}$ after a full term pregnancy and an uneventful delivery. On about 4 days of his life, jaundice developed, but disappeared completely within 2 weeks. About a month later, his mother noticed that the patient had a yellow tinge of the skin and sclerae, and dark urine. At this time he had complaints of moderate fever, anorexia, and vomiting. The patient had been treated for about 10 days, but jaundice persisted. He was brought to our Clinic on Nov. 15, 1961 with a chief complaint of jaundice of 2 weeks' duration.

Physical examination on admission revealed a slightly poorly nourished infant with a remarkable jaundice. There was no eruption over the skin. A few cervical lymph-nodes were palpable, each in the size of a pea, but there was neither tenderness nor fluctuation. The breath sounds were equally strong on both sides. The heart sounds were clear. The abdomen was markedly distended and net-work of the abdominal veins was prominent. The liver was palpable 4 fingerbreadths, firm in consistence, and the spleen was 3 fingerbreadths below the costal margin. Knee-jerks were not exaggerated on both sides, and neither Babinski's sign nor the ankle clonus was elicited. 
Laboratory findings were shown in Table I (cf. Table I). Results of the isohemagglutination tests (Pall-Bunnell) showed the titers of 40:1 on admission and 20: 1 two weeks later. Urinalysis showed positive reactions to both urobilinogen and bilirubin. The blood picture revealed leukocytosis with a remarkable shift to the left and a slight anemia without reticulocytosis. There was a marked lymphocytosis, of which the "atypical lymphocytes (Downey)" were found in $20 \%$. The results of the liver function tests revealed such abnormal findings as hyperbilirubinemia with an increase in direct bilirubin, the positive flocculation reactions and high levels of alkaline phosphatase and of transaminases in serum. Total protein was of $7.2 \mathrm{~g} / \mathrm{dl}$ with hypergammaglobulinemia. The bone marrow picture showed an increased granulopoiesis and no pathologic cells (cf. Table II). Roentgenograms of the chest and bones demonstrated no abnormalities.

Liver biopsy findings (cf. Fig. 1): On the 12th day of admission (about the 4th week after the onset of jaundice), a needle biopsy of the liver was performed. The histological study revealed a remarkable cell infiltration consisting chiefly of mononuclear cells in the portal tracts, showing a granuloma-like appearance in certain areas. The Kupffer cells proliferated and some of them were swollen. Bile thrombi or proliferation of the bile ductuli were not detected. A slight fibrosis in the portal tracts was seen.

TABLE I. Laboratory Findings of an Infant with Jaundice due to Infectious Mononucleosis-Hepatitis

Tuberculin reaction: Negative.

Wassermann's reaction: Negative.

Paul-Bunnell's test: $1: 40,15 / \mathrm{XI}$ (the 15th day after the onset of jaundice). $1: 20,30 / \mathrm{XI}$ (the 30 th day after the onset of jaundice).

Throat swab: Neisseria (H), Streptococcus viridans $(+)$.

Urinalysis: Protein (-), sugar (-), urobilinogen $(+)$, bilirubin (H).

Feces: Occult blood $(-)$, ova of parasites $(-)$, the Schmidt reaction $(t)$.

Blood picture: Red cell count, 3,340,000; hemoglobin, $11.2 \mathrm{~g} / \mathrm{dl}$; hematocrit, 37\%; reticulocytes $10 \%$; white cell count, 20,200 ; basophils $0 \%$, eosinophils $1.5 \%$, lymphocytes $67.5 \%$, monocytes $10 \%$, neutrophils, $21.5 \%$, of which myelocytes $24 \%$, juvenile form $30 \%$, I lobe $40 \%$, II lobes $4 \%$ and III lobes. $0 \%$; platelets count: 150,000 .

Bleeding time: 3 minutes.

Coagulation time: 3-10 minutes.

Capillary fragility test: $110 \mathrm{mmHg}$.

Fragility of erythrocytes to hypotonic saline: $0.36-0.44 \%$.

Serum protein: Total, $7.2 \mathrm{~g} / \mathrm{dl}$; albumin $53.0 \%$, globulin, $\alpha 10.2 \%, \beta 12.2 \%, \gamma 24.5 \%$.

Serum cholesterol: Total, $180 \mathrm{mg} / \mathrm{dl}$; free form $158 \mathrm{mg} / \mathrm{dl}$, esterified form $122 \mathrm{mg} / \mathrm{dl}$.

Liver function tests: Bilirubin in serum, total $5.0 \mathrm{mg} / \mathrm{dl}$, direct bilirubin $3.8 \mathrm{mg} / \mathrm{dl}$; thymol turbidity test 7.5 ; zinc sulfate test 10.5 ; cephalin cholesterol flocculation tests (H); alkaline phosphatase 6.3 Bessey Lowry units; glutamic oxalacetic transaminase in serum $180 \mathrm{u}$.: glutamic pyruvic transaminase in serum $84 \mathrm{u}$.; aldolase in serum 18 units. 
Table II. Bone Marrow Picture of an Infant with Jaundice due to Infectious Mononucleosis-Hepatitis

\begin{tabular}{l|c|c|c}
\hline Nuclear cell count & $39 \times 10^{4}$ & Monocyte & 0.8 \\
Megakaryocyte & $(+)$ & Mitosis & 0.2 \\
M/E & 3.3 & Erythropoiesis & $\%$ \\
Granulopoiesis & $\%$ & Proerythroblast & 0.4 \\
Myeloblast & 4.6 & Megaloblast & 0 \\
Peroxidase (+) & 2.2 & Makroblast & \\
Peroxidase (-) & 2.4 & Basophil & 0.4 \\
Paramyeloblast & 0 & Polychromatic & 2.6 \\
Promyelocyte & 13.8 & Acidophil & 0 \\
Neutrophil leukocyte & & Normoblast & \\
Myelocyte & 16.6 & Basophil & 1.2 \\
Juvenile & 15.2 & Polychromatic & 13.2 \\
Stab & 15.8 & Acidophil & 3.8 \\
Segmented & 0.8 & Mitosis & 0 \\
Eosinophil leukocyte & & Reticuloendothelium & $\%$ \\
Myelocyte & 0.6 & Plasma reticulum & 0.4 \\
Juvenile & 0.2 & Lymphoid reticulum & 0 \\
Stab & 0.4 & Macrophagocyte & 0 \\
Segmented & 0.4 & Plasma cell & 0.4 \\
Basophil leukocyte & & Lymphopoiesis & $\%$ \\
Stab & 0.2 & Lymphoblast & 0 \\
Segmented & 0 & Lymphocyte & \\
Monocyte & & Immature & 0 \\
Monoblast & 0 & Mature & 6.6 \\
Promonocyte & 0.8 & Mitosis & 0 \\
& & &
\end{tabular}

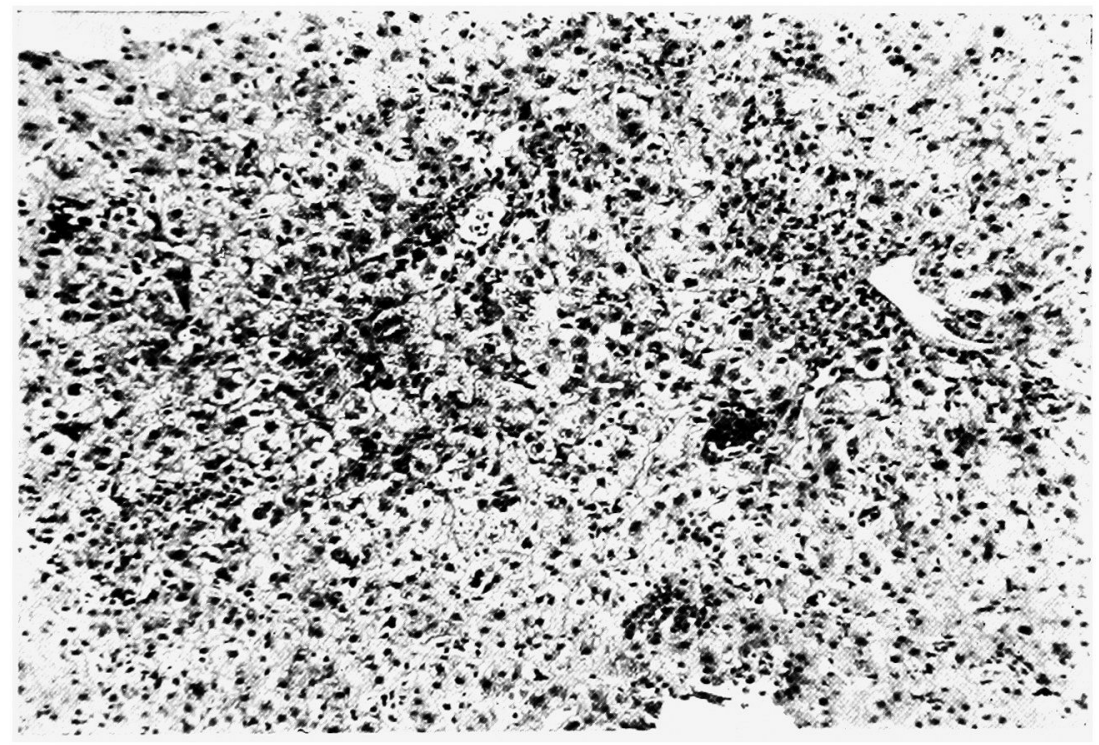

Fig. 1. Light microscopic finding of the liver biopsied on the 4th week after the onset of jaundice. Heavy infiltration of mononuclear cells was observed in portal tracts. (H.E. $100 \times)$ 
Clinical course: High incidence of abnormal lymphocytes in the peripheral blood (cf. Table III) was one of confirmatory evidences for the diagnosis for infectious mononucleosis. Respecting the jaundice, a possibility of the complication with neonatal hepatitis was excluded by the biopsy findings of the liver (discussed elsewhere). Under the diagnosis of infectious mononucleosis-hepatitis oral administration of chloramphenicol was carried out for successive 3 weeks.

TABLE III. Blood Pictures During the Course of an Infant with Jaundice due to Infectious Mononucleosis-Hepatitis

\begin{tabular}{|c|c|c|c|c|c|c|c|}
\hline \multicolumn{2}{|r|}{ Date } & (Week after the onset of jaundice) & $\begin{array}{l}15 / X I \\
(2 \mathrm{nd})\end{array}$ & $\begin{array}{c}29 / \mathrm{XI} \\
\text { (4th) }\end{array}$ & $\begin{array}{c}\text { 16/XII } \\
\text { (6th) }\end{array}$ & $\begin{array}{c}24 / \mathrm{I} \\
(12 \mathrm{th})\end{array}$ & $\begin{array}{l}16 / \mathrm{II} \\
\text { (15th) }\end{array}$ \\
\hline \multicolumn{3}{|c|}{ White cell count } & 20,200 & 16,200 & 17,300 & 18,900 & 18,600 \\
\hline \multicolumn{2}{|c|}{ Basophils } & $\%$ & 0 & 0 & 0 & 0 & 0.5 \\
\hline \multicolumn{2}{|l|}{ Eosinophils } & $\%$ & 1.5 & 1.0 & 1.5 & 0.5 & 1.5 \\
\hline \multicolumn{2}{|c|}{ Lymphocytes } & $\%$ & 67.0 & 52.0 & 68.5 & 74.5 & 78.5 \\
\hline \multicolumn{2}{|l|}{ Monocytes } & $\%$ & 10.0 & 25.0 & 5.0 & 3.0 & 2.5 \\
\hline \multicolumn{2}{|l|}{ Neutrophils } & $\%$ & 21.5 & 22.0 & 24.5 & 18.0 & 16.5 \\
\hline \multirow{6}{*}{ Neutrophils } & Myelocytes & $\%$ & 24 & 8 & 4 & 0 & 0 \\
\hline & Metamyelocytes & $\%$ & 30 & 12 & 12 & 20 & 0 \\
\hline & & $\%$ & 40 & 64 & 54 & 58 & 38 \\
\hline & II & $\%$ & 4 & 16 & 30 & 22 & 48 \\
\hline & III & $\%$ & 0 & 0 & 0 & 0 & 12 \\
\hline & IV & $\%$ & 0 & 0 & 0 & 0 & 2 \\
\hline \multicolumn{2}{|c|}{ Normal lymphocytes } & $\%$ & 80 & 90 & 72 & 95 & 97 \\
\hline \multicolumn{2}{|c|}{ Abnormal lymphocytes } & $\%$ & 20 & 10 & 28 & 5 & 3 \\
\hline
\end{tabular}

TABLE IV. Results of Liver Function Tasts in an Infant with Jaundice due to Infectious Mononucleosis-Hepatitis

\begin{tabular}{|c|c|c|c|c|}
\hline $\begin{array}{c}\text { Date } \\
\text { (Week after the onset of jaundice) }\end{array}$ & $\begin{array}{l}15 / \mathrm{XI} \\
(2 \mathrm{nd})\end{array}$ & $\begin{array}{l}26 / \mathrm{XI} \\
(4 \mathrm{th})\end{array}$ & $\begin{array}{l}16 / \mathrm{XII} \\
(6 \mathrm{th})\end{array}$ & $\begin{array}{l}16 / \mathrm{I} \\
(12 \mathrm{th})\end{array}$ \\
\hline Urine Urobilinogen & + & + & + & + \\
\hline Bilirubin & H & + & \pm & - \\
\hline Serum $\quad\{$ Total bilirubin & 5.0 & 3.0 & 1.4 & 0.6 \\
\hline bilirubin Direct bilirubin $(\mathrm{mg} / \mathrm{dI})$ & 3.8 & 1.3 & 1.2 & 0.2 \\
\hline T.T.T.* & 7.5 & 7.0 & 5.4 & 3.5 \\
\hline Z.S.T.* & 10.6 & 14.0 & 12.0 & 5.6 \\
\hline C.C.F.* & H & $H$ & + & $\ldots$ \\
\hline $\begin{array}{l}\text { Alkaline phosphatase in serum } \\
\text { (Bessey Lowry units) }\end{array}$ & 6.3 & 9.6 & 10.6 & 7.0 \\
\hline S.G.O.T.* & 180 & 112 & 147 & 66 \\
\hline S.G.P.T.* & 84 & 52 & 50 & 32 \\
\hline Serum protein $(g / d l)$ & & 7.2 & & 6.8 \\
\hline$\gamma_{\text {-globulin }}(\mathrm{g} / \mathrm{dl})$ & & 1. 72 & & 1.92 \\
\hline Cholesterol $\quad(\mathrm{mg} / \mathrm{dl})$ & & 180 & & 180 \\
\hline
\end{tabular}

* Note: T.T.T.: Thymol turbidity test

Z.S.T.: Zinc sulphate test

C.C.F.: Cephalin cholesterol flocculation test

S.G.O.T.: Serum glutamic oxalacetic transaminase

S.G.P.T.: Serum glutamic pyruvic transaminase 
After the onset of this treatment, fever persisted for 2 weeks, and jaundice for about a month. The liver, however, was reduced in size gradually and was palpable only 1.5 fingerbreadths below the costal margin about 4 months later. The prominent network of the abdominal wall remained to be visible for about 2 months. The blood pictures were repeatedly examined as were shown in Table III, and showed that a high incidence in abnormal lymphocytes persisted over a period of about a month and that a considerable leukocytosis accompanied with a marked nuclear shift to the left was seen even on the 3rd month of illness. Results of the liver function tests (cf. Table IV) showed abnormal findings as long as 3 months after the onset of illness. However, the general conditions of the patient were relatively good and he had been gaining in weight.

\section{DISCUSSION}

Symptomatology of infectious mononucleosis has been said ${ }^{10,11)}$ to be protean. Jaundice observed in infectious mononucleosis - icteric type of infectious mononucleosis-hepatitis - was found only in $8 \%$ of the cases of this disease which were experienced by Hoagland. ${ }^{12}$ ) According to de Vries, ${ }^{13)}$ jaundice might develop prior to or simultaneously with the enlargement of lymph-nodes or the disease was not accompanied by any other signs except jaundice. Within our knowledge, there has been no report of an infantile case of infectious mononucleosis with jaundice, even though hepatitis without jaundice in infectious mononucleosis was reported in infancy.14) A marked increase in myelocytes in the peripheral blood and a marked shift to the left of neutrophil nuclei were found in our own case and these hematological findings were said, according to Scheer, ${ }^{6}$ ) to be characteristic for infantile cases of this disease. In our case the titers of Paul-Bunnell's test were 1:40-1:20. Even though these titers were not so high as in adult cases, it might be considered as a positive evidence for the diagnosis of infectious mononucleosis, because a formation of the heterophil antibodies might be deficient in early age of life as Misao ${ }^{15}$ ) showed the absence of the heterophil antibodies in serum in newborn period. Regarding the results of the liver function tests, it may be worthy to note that the positive flocculation reaction was, together with a high level of serum transaminases, ${ }^{16,23)}$ found even in the early stage of infectious mononucleosis, because a high level of serum transaminases without being accompanied by the positive flocculation reactions was said to be characteristic of neonatal hepatitis (giant cell hepatitis) ${ }^{24}$. The histological findings of the liver in infectious mononucleosis consisted of an infiltration of mononuclear cells in the portal tracts and sinusoids, a slight change in hepatic parenchyma and no changes in the hepatic architecture. Histological findings of the liver biopsied from our own case showed a good accordance with the findings above quoted. These histological findings were never found in giant cell hepatitis $^{22}$ as well as in atresia of bile ducts. ${ }^{22}$ 


\section{SUMMARY}

A 2 month-old infant with jaundice due to infectious mononucleosis-hepatitis - probably the youngest patient ever reported with jaundice due to infectious mononucleosis - was described.

The liver biopsy findings and peripheral blood pictures were emphasized from the diagnostic point of view.

\section{References}

1) Katzumata, T., Rinshonaikashonika (Jap.), 1950, 5, 406.

2) Kagaya, E., Shonikarinsho (Jap.), 1954, 7, 214.

3) Tazaki, K., \& Matzuzaki, Y., Rinshonaikashonika (Jap.), 1956, 11, 23.

4) Matzumoto, Y., Rinshoshoniigaku (Jap.), 1956, 4, 572.

5) West, J.P., Arch. Pediat., 1896, 13, 889.

6) Scheer, K., Monatschr, f. K.H.K., 1930, 48, 59.

7) Davis, C.M., J.A.M.,A., 1929, 92, 1417.

8) Price, J.P., Am. J. Dis. Child., 1930, 40, 581.

9) Scheer, K., Monatschr. f. K.H.K., 1932, 52, 398.

10) Tidy, H.L., Lancet, 1934, 227, $180 \& 230$.

11) Sakamoto, H., \& Kumagai, N., Nihonrinsho (Jap.), 1951, 9, 120.

12) Hoagland, R.J., Am. J. Med. Sc., 1960, 240, 21.

13) de Vries, S.I., Acta Med. Scand., 1938, 95, 552.

14) Hsia, D.Y. \& Gellis, S.S., Am. J. Dis. Child., 1952, 84, 175.

15) Misao, T., Saishinigaku (Jap.), 1960, 15, 1788.

16) Nelson, R.S. \& Darrhagh, J.H., Am. J. Med., 1956, 21, 26.

17) Kumagai, H., Saishinigaku (Jap.), 1960, 15, 1768.

18) Schiff, L., Disease of the Liver, 1956, Lippincott.

19) Van Beek, C. \& Ch Hack, A.J., Acta Med. Scand., 1943, $113,125$.

20) Bang, J. \& Wansher, O., Acta Med. Scand., 1945, 120, 436.

21) Craig, J.M. \& Landing, B.H., Arch. Path., 1952, 54, 321.

22) Myers, R.L., et al., Pediatrics, 1956, 18, 767.

23) Roalki, B.S., Johnes, T.G. \& Verney, A.F., Brit. Med. J., 1960, 1, 929.

24) Myers, R.L. et al., Pediatrics, 1956, 18, 767. 